\title{
Production and optimization of single cell protein from orange peels by Saccharomyces cerevisiae
}

\author{
M. A. Milala, M. Yakubu, B. Burah*, H. H. Laminu and H. Bashir \\ Department of Biochemistry, Faculty of Science, University of Maiduguri, Maiduguri, Nigeria \\ *Corresponding author. Email: bulama19@gmail.com
}

Copyright $@ 2018$ Milala et al. This article remains permanently open access under the terms of the Creative Commons Attribution License 4.0, which permits unrestricted use, distribution, and reproduction in any medium, provided the original work is properly cited.

Received 30th August, 2018; Accepted 20th September, 2018

\begin{abstract}
Deficiency in protein is increasing worldwide especially in developing countries. Protein from microbial biomass termed as Single Cell Protein (SCP) can be considered as an alternative to conventional source of food. This research work was carried out to produce single cell protein from orange peels by Saccharomyces cerevisiae isolated from spoilt tomato fruit and to optimize cultural condition in order to obtain a maximum amount of biomass concentration thus, the protein quantity. The proximate content of the peel was analysed using standard method. Carbohydrates was $59.96 \%$, fibre $(14.03 \%)$, moisture $(12.07 \%)$, fat $(9.11 \%)$, ash $(5.21 \%)$ and protein $(1.02 \%)$. Results of this study revealed that the optimum $\mathrm{pH}$ in which a maximum growth $(1790 \mathrm{ppm})$ of biomass was obtained was at $\mathrm{pH} 7.0$ after 120 hours of incubation. The effect of Incubation temperature showed that maximum biomass growth $(1145 \mathrm{ppm})$ was obtained at $37^{\circ} \mathrm{C}$ after 96 hours of incubation. Effect of substrate concentration revealed that biomass concentration increased with increase in substrate concentration. Maximum protein with minimal nucleic acid content was obtained at incubation temperature of $37^{\circ} \mathrm{C}$. In conclusion, it may not be favourable to incubate the fermentation medium at temperature above $55^{\circ} \mathrm{C}$ and $\mathrm{pH}$ below 4.0 for production of SCP using Saccharomyces cerevisiae.
\end{abstract}

Key words: Nucleic acid, orange peel, Saccharomyces cerevisiae, single cell protein.

\section{INTRODUCTION}

Protein is a nutrient needed for normal growth and maintenance of human body. Proteins (made up of amino acids) are important dietary constituents because they are required for the structure, function, and regulation of the body's major tissues and organs. Protein deficiency in food may pose a problem because essential amino acids, which cannot be synthesized by the body itself, are not replenished (Hermann and Janice, 2002). The increasing world deficiency of protein is becoming a main problem of humankinds. Since the early fifties, intense efforts have been made to explore new, alternate and unconventional proteins. For this reason, in 1996, new sources mainly yeast, fungi, bacteria and algae named Single Cell Protein (SCP) as coined to describe the protein production from biomass, originating from different microbial source. Microbial biomass has been considered an alternative to conventional source of food or feed. (Parajo et al., 1995).

Single cell protein production technologies arose as a promising way to solve the problem of worldwide protein shortage. They evolved as bioconversion processes which turned low value by-products, often wastes, into products with added nutritional and market value. Single Cell Protein is one of the most important steps for this goal and is an alternative and an innovative way to successfully solve the global food problems (Ugalde and Castrillo 2002).

Production of single cell protein is achieved through action of different microorganism on variety of substrate. The classes of microorganisms capable of carrying out the task include; yeast, fungi, bacteria and algae (Roth 1980). Yeast was the first microorganism whose importance as animal feed supplement was recognized almost a century ago. Yeast is considered suitable for single cell production because of its superior nutritional quality. The supplementation cereals with single protein especially yeast, make them as good as animal protein (Huang and 
Kinsella, 1986). It is on this background that this study is designed to produce and optimize single cell protein from fruit waste using yeast (Saccharomyces cerevisiae).

\section{MATERIALS AND METHODS}

\section{Sample collection and media preparation}

Orange peels and spoilt tomato fruits were collected from Maiduguri Monday Market, Borno State, Nigeria in a tightly closed container. An amount of $200 \mathrm{~g}$ of orange peels was dried at $105^{\circ} \mathrm{C}$ for 24 hours (AOAC, 2016), then ground with mortar and pestle to smaller particles and pretreated with $20 \% \mathrm{H}_{2} \mathrm{SO}_{4}$, neutralized with $1 \mathrm{M} \mathrm{NaCl}$ and washed with distilled water. The nutrient broth liquid medium used was adapted from Adnan et al. (2011). It contained in percentage (w/v): $0.5 \% \mathrm{MgSO}_{4}, 0.5 \% \mathrm{KH}_{2} \mathrm{PO}_{4}, 0.01 \%$ $\mathrm{FeSO}_{4}, 0.12 \% \mathrm{Na}_{2} \mathrm{SO}_{4}, 5 \%$ glucose and was prepared in distilled water added with $0.2 \%$ of Tween- 80 . The medium for the fermentation procedure was prepared using orange peel $10 \%(\mathrm{w} / \mathrm{v})$ of nutrients broth and final $\mathrm{pH}$ was adjusted to $7.00 \pm 0.03$.

\section{Isolation of microorganism}

Yeast specie (Saccharomyces cerevisiae) was isolated from spoilt tomato fruit waste using standard laboratory method. Saccharomyces cerevisiae was identified by its morphological characteristics based on the method described by Samson (2001).

\section{Determination of proximate composition}

The proximate composition of orange peel was determined using the standard methods of AOAC (2005). The parameters were: fats, ash and fibre. Moisture content was determined by the method based on the principle of drying to constant weight (AOAC, 2000). The micro-Kjeldahl method was employed to determine the total nitrogen and the crude protein $(\mathrm{N} \times 5.95)$ (AOAC, 2000). Total carbohydrate was calculated by the difference method (summing the values of moisture, crude protein, ash, and crude fat and subtracting the sum from 100).

\section{Optimization of SCP production}

\section{Effect of substrate concentration on SCP production}

The effect of substrate concentration (pretreated orange peels) was determined by varying substrate concentration $(2,4,6,8$ and $10 \mathrm{~g} / \mathrm{L})$ of the media incubated at $37^{\circ} \mathrm{C}$ and the biomass concentration was read at an interval 24 hours for 120 hours.

\section{Effect of $\mathrm{pH}$ on SCP production}

In the determination of effect of $\mathrm{pH}$, the above procedure was observed, but a constant substrate concentration of 2 $\mathrm{g}$ was used while the $\mathrm{pH}$ of the media were varied from $4.0,5.0,7.0,8.0$ and 9.0. The biomass concentrations were read at an interval 24 hours for 120 hours.

\section{Effect of temperature on SCP production}

The effect of temperature on SCP production was examined by incubating the media at different incubation temperatures of $37,45,50$ and $55^{\circ} \mathrm{C}$ after $24,48,72,96$ and 120 hours of incubation.

\section{Protein concentration at various temperatures}

The protein quantity produced at different incubation temperatures was determined using biuret method of protein determination in which bovine serum albumin was used as standard protein.

\section{Nucleic acid concentration at various temperatures}

The nucleic acid concentration in the SCP produced at different incubation temperature was determined by spectrophotometric analysis of nucleic acids based on the principle that a liquid sample containing nucleic acid absorbs UV light at $260 \mathrm{~nm}$ wavelength (the amount of light absorbed is directly proportional to the quantity of nucleic acid present in the sample (Huss et al., 1983).

\section{RESULTS AND DISCUSSION}

The result in Figure 1 showed the proximate composition of orange peel. Carbohydrate content was the highest $(59.96 \%)$, followed by fibre $(14.03 \%)$, moisture $(12.07 \%)$, fat $(9.11 \%)$, ash $(5.21 \%)$ while the least was protein content $(1.02 \%)$. This proximate composition of fruit waste is comparable with the result of Bacha et al. (2011).

The effect of different substrate concentration on the biomass production is shown in Figure 2. The maximum biomass concentration (1690 ppm) was observed at substrate concentration of $10 \mathrm{~g} / \mathrm{L}$ after 120 hours of incubation. As the substrate concentration increased the rate of growth was increasing as well as biomass concentration. Amit et al. (2012) also reported that substrate concentration is directly proportional to biomass production when cucumber peel was used as substrate.

The effect of different $\mathrm{pH}$ on the growth and production of biomass is presented in Figure 3. Maximum growth (1790 ppm) was observed at pH 7.0 after 120 hours of incubation while the least growth was observed at acidic 


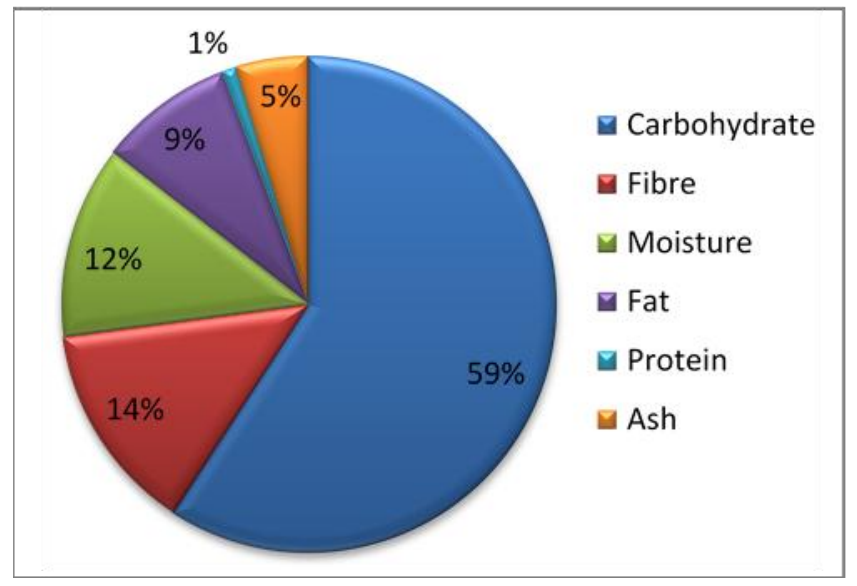

Figure 1. Proximate composition of orange peel.

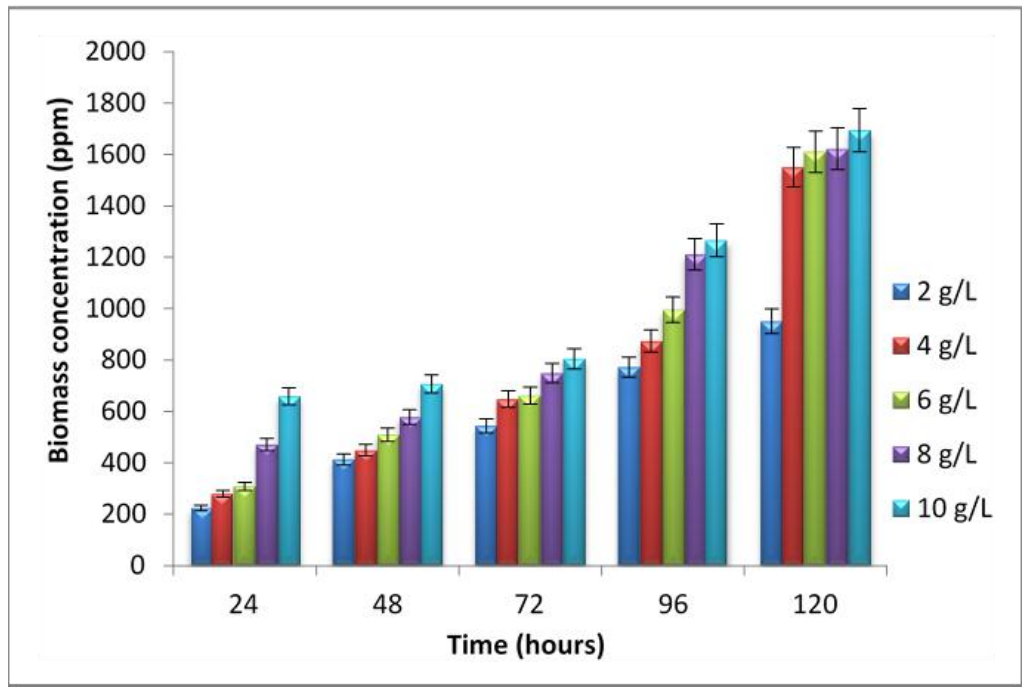

Figure 2. Effect of substrate concentration on biomass production.

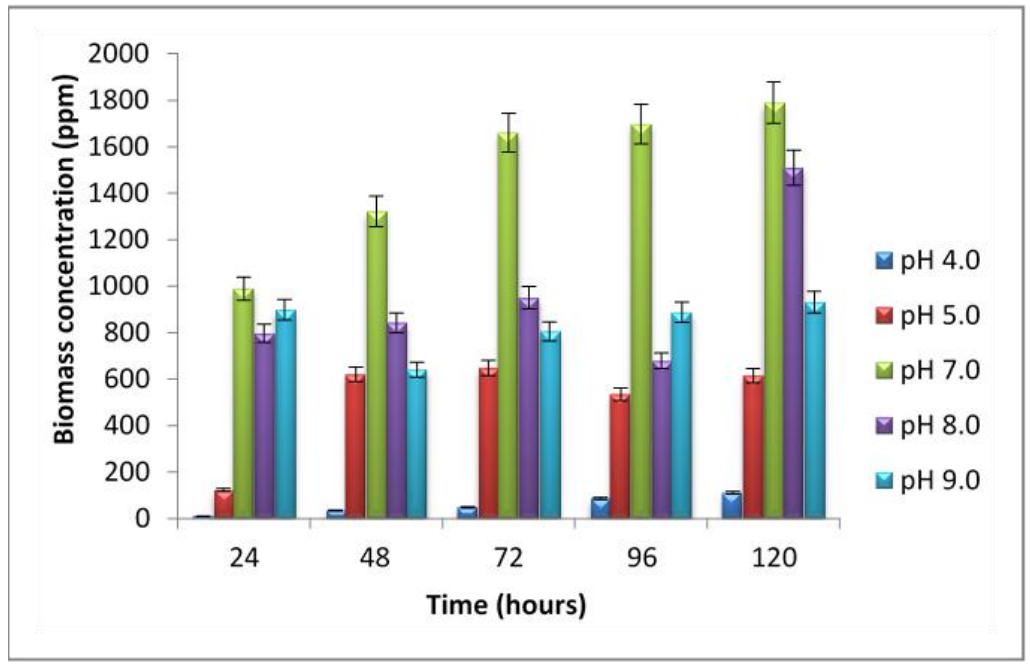

Figure 3. Effect of $\mathrm{pH}$ on biomass production. 


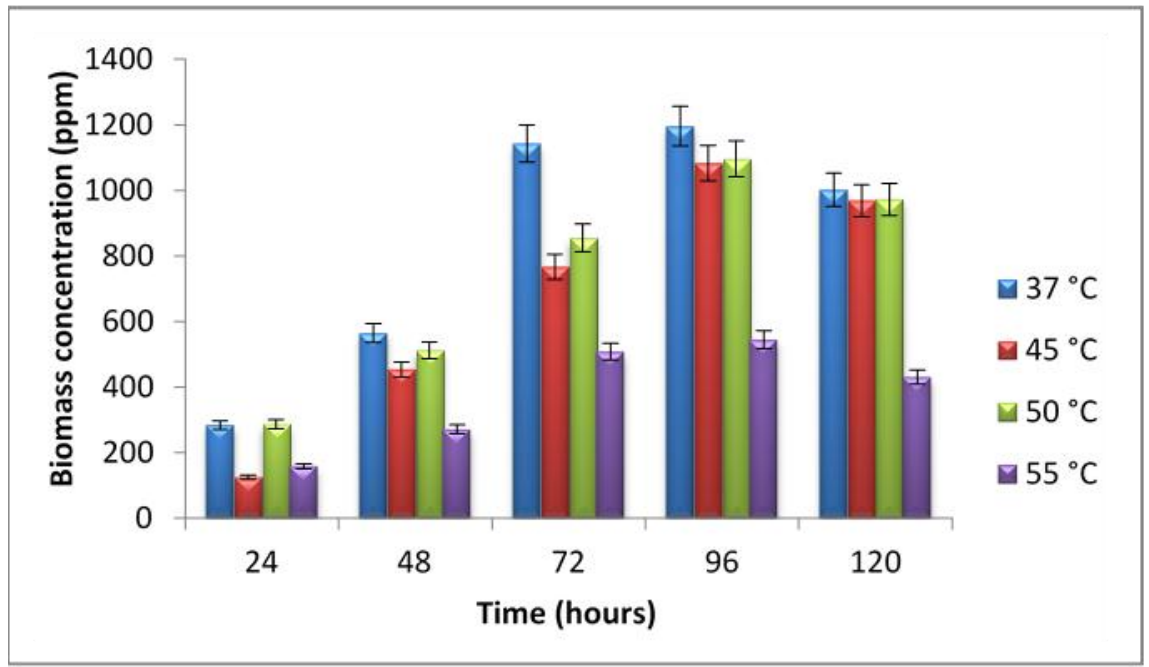

Figure 4. Effect of temperature on biomass production.

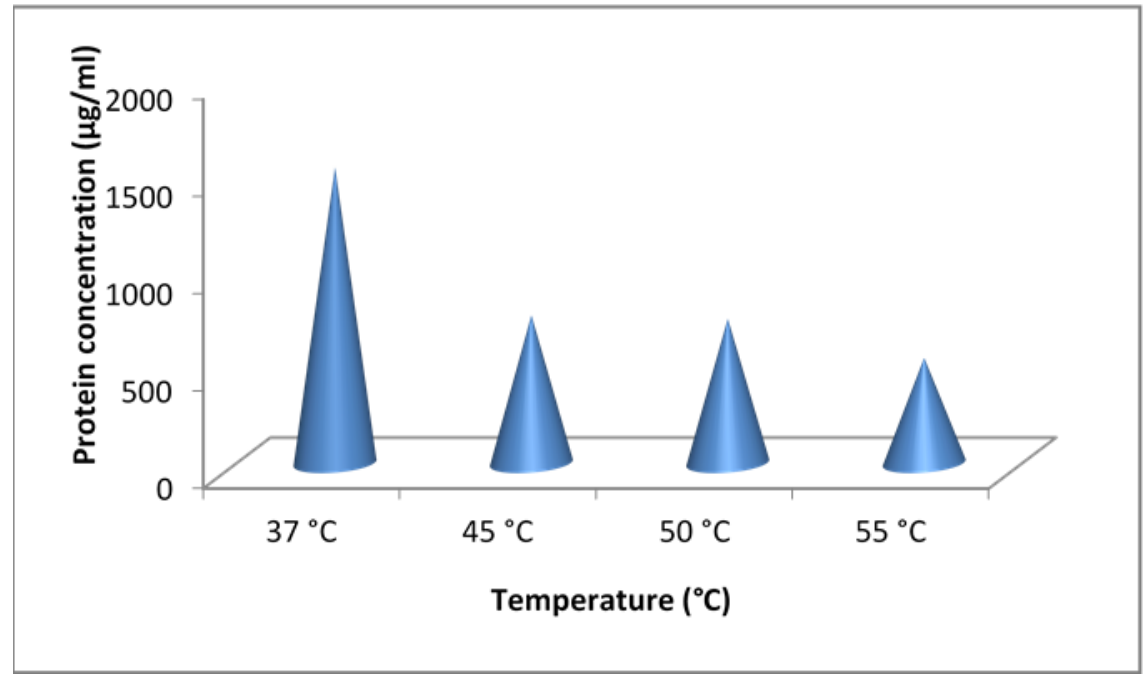

Figure 5. Quantity of protein obtained at different temperature.

$\mathrm{pH}$ of 4.0. The $\mathrm{pH}$ of the medium is also an interesting factor in optimizing biomass production, thus protein quantity. Microorganisms are very sensitive to the $\mathrm{pH}$ of their growth media. Similar observations have also been reported by Bacha et al. (2011).

The effect of different incubation temperature on biomass production is shown in Figure 4. Maximum biomass production (1145 ppm) was obtained at $37^{\circ} \mathrm{C}$ after 96 hours of incubation while least biomass production was observed at $55^{\circ} \mathrm{C}$. Among all factors that affect microbial growth, temperature is probably one of the most important factors directly affecting the growth of microorganism (Daud et al., 1978). Ojokoh and Uzeh (2005) reported $25^{\circ} \mathrm{C}$ ideal temperature for the maximum protein production by $S$. cerevisiae.
Figure 5 is the different quantities of protein obtained at different incubation temperature in which maximum protein concentration of $1,520 \mu \mathrm{g} / \mathrm{ml}$ was obtained at $37^{\circ} \mathrm{C}$ while the least protein concentration $(541 \mu \mathrm{g} / \mathrm{ml})$ was obtained at incubation temperature of $55^{\circ} \mathrm{C}$. Higher percentage of protein $(60.31 \%)$ was found in yeast biomass when $S$. cerevisiae was grown on banana peel rich media at $37^{\circ} \mathrm{C}$ (Amit et al., 2012).

The different quantities of nucleic acid obtained at different incubation temperature is shown in Figure 6 in which minimum nucleic acid concentration of $107.7 \mathrm{ng} / \mathrm{uL}$ was obtained at $37^{\circ} \mathrm{C}$. In humans, excessive intake of nucleic acid is toxic due to the limited capacity of urinary excretion of the uric acid formed from nucleotide catabolism (Schulz and Oslage, 1976). This result is in 


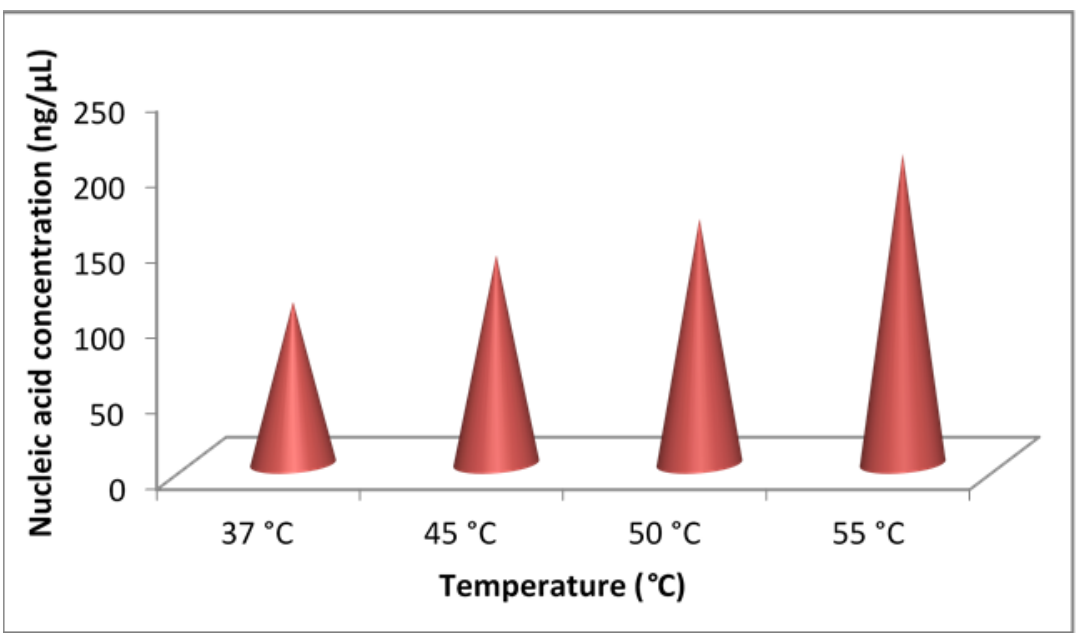

Figure 6. Quantity of nucleic acid obtained at different temperature.

contrast with the result of Yakoub and Umar (2010) who reported that maximum nucleic acid concentration from Saccharomyces cerevisiae was obtained when incubated at $45^{\circ} \mathrm{C}$.

\section{Conclusion}

In conclusion, results of this study indicated that Saccharomyces cerevisiae isolated from spoiled tomato fruit is capable of growing and converting carbohydrate rich orange peels into edible microbial protein (SCP). The substrate concentration holds a direct correlation with growth of the organism, thus production of single cell protein. To optimize the biomass production optimum $\mathrm{pH}$ and temperature of 7.0 and $37^{\circ} \mathrm{C}$ respectively is recommended. Maximum quantity of protein with minimal nucleic acid content was relatively obtained at incubation of $37^{\circ} \mathrm{C}$ at neutral $\mathrm{pH}$.

\section{CONFLICT OF INTEREST}

The authors declare that they have no conflict of interest.

\section{ACKNOWLEDGEMENTS}

We acknowledge the contributions of Mr. Joshua Bitrus Ndirmbula of Department of Crops Protection, Faculty of Agriculture in all the stages of this study.

\section{REFERENCES}

Adnan, A., Mushtaq, Z., Syed, Q., Shabbiri, K. (2011). Optimization of fermentation parameters for the production of L-lysine from Brevibacterium linens DSM 20158, using statistical approach. World Applied Sciences Journal, 13(5), 1132-1140.
Amit, K. M., Samadrita, S., Jayati, B., \& Bhattacharya, D. K. (2012). Utilization of fruit wastes in producing single cell protein. International Journal of Science, Environment and Technology, 1(5), 430-438.

AOAC (2000). Official Methods of Analysis, Association of official Analytical Chemists, Washington, DC, USA, 17th edition.

AOAC (2005). Official Methods of Analysis, Association of official Analytical Chemists, Washington, DC, USA, 19th edition.

AOAC (2016). The official methods of analysis of AOAC International, 20th edn. George W. Latimer, Jr. 3172p. Available at http:// www.eoma.aoac.org.

Bacha, U., Nasir, M., Khalique, A., Anjum, A. A., \& Jabbar, M. A. (2011). Comparative assessment of various agro-industrial wastes for Saccharomyces cerevisiae biomass production and its quality production as a single cell protein. Journal of Animal and Plant Sciences, 21(4), 844-849.

Daud, A., Servais, F., Metailler, R., Huelvan, C., Desbruyeres, E., (1978). Production of single cell protein from Saccharomyces cerevisiae by utilizing fruit wastes. Aquaculture, 141, 107-127.

Hermann, K., \& Janice, Y., (2002). Partial replacement of fishmeal by brewer's yeast (Saccaromyces cerevisae) in diets for Sea Bass (Dicentrarchus labrax) Juveniles. Aquaculture, 202, 269-278.

Huang, C., \& Kinsella, Y. (1986). A perspective on piotechnological potential of micro algae. Critical Review of Microbiology, 34, 77-88.

Huss, O., Moharib, S. A., \& Jwanny, E. W. (1983). Protein and other compositional analysis of Saccharomyces fragilis grown on coconut water waste. Journal of Applied Bacteriology, 41, 97-107.

Ojokoh, A. O., \& Uzeh, R. E. (2005). Production of Saccharomyces cerevisiae Biomass in Papaya Extract Medium. African Journal of Biotechnology, 4(11), 1281-1284.

Parajo, J. C., Santos, V., Dominguez, H., \& Vazquez, M. (1995). $\mathrm{Na}_{2} \mathrm{OH}-\mathrm{Based}$ Pretreatment for Improving the Nutritional Quality of Single Cell Protein. Journal of Applied Biochemistry and Biotechnology, 55, 133-149.

Roth, F. X. (1980). Microorganism as a Source of Protein for Animal. Animal Research Development, 12, 7-19.

Samson, R. A. (2001). Introduction to Food Borne Microorganisms, American Society of Microbiology, America, Pp. 196-197. 
Schulz, E., \& Oslage, H. J. (1976). Composition and nutritive value of single cell protein (SCP). Animal Feed Science and Technology, Pp. 9-24.

Ugalde, T., \& Castrillo, L. (2002). Single cell protein. Cambridge, MA: MIT Press: UK. Pp. 57-68.
Yakoub, K.. M., \& Umar, D. M. (2010). Effect of various agriculture wastes and pure sugars on the production of single cell protein by Penicillium expansum. World Applied Sciences Journal, 8, 80-84. 